\title{
Decomposition of tree leaf litter on pavement: implications for urban water quality
}

\author{
Sarah E. Hobbie • Lawrence A. Baker • \\ Christopher Buyarski • Daniel Nidzgorski • \\ Jacques C. Finlay
}

(C) Springer Science+Business Media New York 2013

\begin{abstract}
Leaf litter may be an important source of nutrients to stormwater and ultimately contribute to eutrophication of surface waters associated with urbanization. Thus, understanding decomposition and nutrient release from leaf litter that falls on impervious surfaces is important for stormwater management. However, few studies have examined leaf litter decomposition in the unique urban environment of the street gutter. We compared decomposition of leaf litter of five street tree species in a parking lot gutter in St. Paul, Minnesota, USA. In contrast to our expectations, comparisons with past studies revealed that litter decomposed more rapidly in the gutter than in nearby natural areas. And decomposition rates were as rapid as those measured in other urban settings (forests and streams), with most species losing $80 \%$ of their initial mass after 1 year. Litter of most species had retained more than half of its initial $\mathrm{N}$ and $\mathrm{P}$ after 1 year. However, in contrast to $\mathrm{N}$, litter $\mathrm{P}$ dynamics largely were uncoupled from litter mass dynamics, with litter $\mathrm{P}$ increasing and decreasing unpredictably over the year. Shortterm $(24 \mathrm{~h})$ laboratory studies revealed that litter had the potential to lose a high fraction of its initial $\mathrm{P}$, with high variation among species (from 27 to $88 \%$ ), and a smaller fraction of its initial $\mathrm{N}(<10 \%)$ via leaching. Thus, street tree species may differ in their potential contributions to nutrients that are released during decomposition. Our results suggest that careful selection of street tree species and timely removal of litterfall have significant potential to reduce nutrient fluxes from streets to storm drains, particularly for P.
\end{abstract}

Keywords Leaf litter decomposition $\cdot$ Nitrogen $\cdot$ Phosphorus $\cdot$ Street tree $\cdot$ Urban

\section{Introduction}

Leaf litter decomposition is a well-studied process in natural and managed ecosystems because of its role in ecosystem carbon budgets, soil organic matter formation, and nutrient

S. E. Hobbie $(\bowtie) \cdot$ C. Buyarski $\cdot$ D. Nidzgorski $\cdot$ J. C. Finlay

Department of Ecology, Evolution and Behavior, University of Minnesota, St. Paul, MN 55108, USA

e-mail: shobbie@umn.edu

L. A. Baker

Department of Bioproducts and Biosystems Engineering, University of Minnesota, St. Paul, MN 55108, USA 
cycling. Decomposition has been less studied in urban environments, and past terrestrial urban decomposition studies mostly focused on comparisons along urban to rural gradients (e.g. McDonnell et al. 1997) and on the effects of urban pollution on litter chemistry and decomposability (Fritze 1988; Cotrufo et al. 1995; Carreiro et al. 1999). When comparing decomposition rates among forest stands of similar age and composition across urban to rural gradients, these studies found that decomposition rates were sometimes more rapid in the urban environment, likely because of warmer temperatures and more earthworms in urban stands (Pouyat et al. 1997; Pouyat and Carreiro 2003). Similarly, decomposition can be more rapid in urban streams likely because of higher temperatures and greater nutrient availability (Imberger et al. 2008). But in another study, decomposition rates were slower in the urban environment, perhaps because of reduced fungal abundance in urban soils (PavaoZuckerman and Coleman 2005).

Less well known is how decomposition proceeds in the novel environments created by urbanization. For example, urban areas are characterized by high impervious surface area (Nowak and Greenfield 2012), such that considerable leaf litter in the urban environment falls on streets or parking lots (or is swept or blown into them). From there, litter is transported into storm drainage networks, removed through street sweeping operations, or transported to pervious surfaces by wind. The amount of decomposition and nutrient release from leaf litter that occurs when litter falls on impervious surfaces is unknown.

Understanding litter decomposition and nutrient release on impervious surfaces is important in the context of stormwater management. There is growing interest in reducing nutrient sources to streets (i.e., "source reduction") to improve water quality in urban lakes, particularly since downstream best management practices are expensive to install and maintain. Because leaves can contribute a significant portion of the phosphorus $(\mathrm{P})$ to the material that collects in streets (Waschbusch et al. 1999), street sweeping has received renewed interest as a mechanism for reducing nutrient loads to storm drain networks (Selbig and Bannerman 2007). Better knowledge of decomposition dynamics of leaf litter in the street can inform street sweeping operations by providing information on how much mass and nutrient loss occurs if street sweeping is delayed following leaf drop.

Our goals were to compare decomposition and litter nutrient dynamics among tree species commonly planted in boulevards adjacent to streets when decomposing in a gutter, and in turn to compare those dynamics qualitatively to those determined in nearby natural areas and other urban environments in past studies. We expected that decomposition would occur slowly in the gutter relative to natural areas because of lack of contact between leaf litter and soil, and associated decomposer microbes, nutrients, and moisture that promote decomposition. Further, we expected that litter decomposing in the gutter might not exhibit typical patterns of nutrient immobilization (net nutrient incorporation into litter by colonizing decomposer microbes) and nutrient release (e.g. Staaf and Berg 1981), since nutrient immobilization might be reduced by lack of contact with nutrient sources for immobilization.

\section{Methods}

\section{Leaf litter decomposition}

The study took place in St. Paul, Minnesota, USA. Decomposition was measured for litter collected from five deciduous trees that are commonly planted as street trees (on boulevards adjacent to streets) in Minneapolis-St. Paul, MN: Acer platanoides L. (Norway maple), Acer 
$x$ fremanii (Freeman maple), Fraxinus pennsylvanica Marsh. (green ash), Quercus bicolor Willd. (swamp white oak), and Tilia cordata Mill. (little leaf linden). We collected freshly fallen leaf litter, air-dried it, and enclosed $10 \mathrm{~g}$ litter into $20 \mathrm{~cm} \times 20 \mathrm{~cm}$ bags, constructed of 1 -mm mesh fiberglass window screen.

Subsamples of fresh (air-dried) litter $(n=3)$ were analyzed for ash mass by combustion in a muffle furnace $\left(600{ }^{\circ} \mathrm{C}\right.$ for $\left.6 \mathrm{~h}\right)$; for total carbon $(\mathrm{C})$ and nitrogen $(\mathrm{N})$ on a Costech ECS4010 element analyzer (Costech Analytical, Valencia, California, USA) at the University of Nebraska, Lincoln; for total phosphorus (P) by digestion with $10 \mathrm{~N}$ sulfuric acid after ashing samples at $300{ }^{\circ} \mathrm{C}$ for $30 \mathrm{~min}$. followed by $500{ }^{\circ} \mathrm{C}$ for $2 \mathrm{~h}$ (De Mott et al. 1998); and for carbon fractions (cell solubles, hemicellulose + bound protein, cellulose, and lignin + other recalcitrants) using an ANKOM Fiber Analyzer (Ankom Technology, Macedon, New York, USA).

Sufficient bags were made to harvest four replicates for each species 15 times over the course of 1 year. We deployed bags approximately $20 \mathrm{~cm}$ apart in the gutter of a concrete combined curb and gutter in the parking lot of the University of Minnesota Equine Center, St. Paul, MN on Oct. 1, 2010. This location was chosen because the parking lot is large, but little used, so it has abundant linear meters of curb but is not prone to vandalism. The parking lot is constructed with a slope such that most of precipitation flows away from the curbs and towards a central drain. Once per week, a car was driven over the bags to simulate car parking that would minimally occur along curbs on city streets. There was minimal traffic along the curbs otherwise.

Four replicate bags were harvested every 2 weeks through December, 2010 and approximately monthly thereafter through October 1, 2011. No bags were harvested during February 2011 due to deep snow cover. Upon collection, we separated litter from bags, and dried to constant mass $\left(65^{\circ} \mathrm{C}\right)$, weighed, and ashed litter (as above) to determine ashfree dry mass remaining as a proportion of the initial ash-free dry mass. Harvested litter was analyzed for $\mathrm{C}, \mathrm{N}$, and $\mathrm{P}$ mass, as above.

\section{Decomposition statistical analyses}

We fit proportion of initial ash free dry mass remaining at each harvest date to three alternative exponential decay models (Wieder and Lang 1982) using general maximum likelihood estimation with the bbmle package in R (version 2.15), which compares model fits using Akaike's Information Criterion (AIC) (R version 2.10.1, R Development Core Team). The three models were (1) single exponential $\left(X=e^{-k_{s} t}\right)$ where $X$ is the proportion of initial mass remaining at time $t$ and $k_{S}$ is the decomposition constant; (2) double exponential $\left(X=M e^{-k_{\text {fast }} t}+(1-M) e^{-k_{\text {slowt }} t}\right)$ where $M$ is the "fast" fraction of the initial mass that decomposes with decomposition rate $k_{\text {fast }}$, while the remaining "slow" fraction (1 - $M)$ decomposes with rate $k_{\text {slow }}$; and (3) asymptotic $\left(X=A+(1-A) e^{-k_{A} t}\right)$, where $A$ is the fraction of the initial mass with a decomposition rate approaching zero (i.e., the asymptote), while the remaining fraction $(1-A)$ decomposes with rate $k_{A}$. For each species, all replicates were pooled for model fitting. We examined the relationships between mean initial litter chemistry for all species and decomposition parameters from each species' best-fit model.

We compared decomposition among species statistically at the end of the fast fraction decomposition period and at the end of the entire experiment, as follows. Because the double exponential model ended up being the best fit for most species (see Results), using that model, we calculated the time, $t$, at which the litter reached the proportion mass remaining equal to the proportion in the slow fraction $(1-M)$, on average (0.04 years). Then, we compared mass remaining among all species at 0.04 years and at the end of the experiment (1 year) using one-way ANOVA. 


\section{Leaf litter leaching}

To determine the readily leachable $\mathrm{N}$ and $\mathrm{P}$ for each litter type, $5 \mathrm{~g}$ of air-dried leaf litter of each species were placed in $500 \mathrm{ml}$ of deionized water in $1 \mathrm{~L}$ wide-mouth high-density polyethylene bottles ( 5 replicates/species). Samples were shaken by hand for $10 \mathrm{~s}$, by holding the bottles in a horizontal position and agitating back and forth, and were then allowed to sit at $22{ }^{\circ} \mathrm{C}$ until subsampling, when they were shaken again by hand for $10 \mathrm{~s}$. Duplicate $30 \mathrm{ml}$ subsamples of leachate were taken after $30 \mathrm{~min}$ and again after $24 \mathrm{~h}$, syringe-filtered through pre-ashed GF/F filters, and analyzed for dissolved organic C (DOC), total dissolved $\mathrm{N}(\mathrm{TDN})$, dissolved inorganic $\mathrm{N}$ (DIN), soluble reactive $\mathrm{P}$ (SRP), and total dissolved P (TDP). Dissolved organic N (DON) and P (DOP) were calculated by subtracting DIN and SRP from TDN and TDP, respectively.

\section{Results}

For three of the five species, Acer platanoides, Acer $x$ freemanii, and Tilia cordata, the double exponential model was the best fit to the data. For the remaining two species, Fraxinus pennsylvanica, and Quercus bicolor, the fits of the three different exponential models were indistinguishable (AIC values for the three models differed by $<3$ units), so we present the results of the double exponential model for ease of comparison among species (Table 1), although for Fraxinus pennsylvanica, the double exponential model fit collapsed to a single exponential decay model (i.e., $M=0$ ). Regressions of observed mass remaining against that predicted by the double exponential decay models had $\mathrm{R}^{2}$ values ranging from $0.80-0.86$ among species. Visual inspection of model fits showed that, not surprisingly, the model over-predicted mass loss during winter (Fig. 1) when litter was mostly frozen and decomposing slowly and under-predicted mass loss during the warmest and wettest summer period (Fig. 1), after 0.8 years, when both decomposition rates and leaching losses likely were high (not shown).

Across all species, a small fraction (from 0-22\%) of the initial mass decomposed extremely rapidly (Table 1 ). The decomposition rate of this fraction, $k_{\text {fast }}$, was significantly negatively related to the initial lignin concentration of the litter $(r=-0.91, P=0.03)$, as was the decomposition rate of the slow fraction, $k_{\text {slow }}(r=-0.90, P=0.04)$. These negative correlations were driven by the high initial lignin concentration and relatively slow decomposition rates (both $k_{\text {fast }}$ and $k_{\text {slow }}$ ) of Quercus bicolor (Table 2). The sizes of the fast and slow fractions (note that they add up to one and are perfectly negatively correlated with one another) were positively and negatively related to the initial litter $\mathrm{N}$ concentration, respectively (Pearson's $r=-0.95$ or 0.95 , respectively, $P=0.04$ ). These relationships were driven by

Table 1 Parameters for a double exponential decay models fit to proportion ash-free dry mass remaining by species

\begin{tabular}{lcccl}
\hline Species & $\begin{array}{c}k_{\text {fast }} \\
\left(\mathrm{y}^{-1}\right)\end{array}$ & $\begin{array}{c}k_{\text {slow }} \\
\left(\mathrm{y}^{-1}\right)\end{array}$ & $\begin{array}{l}\text { Fraction } \\
\text { fast }(M)\end{array}$ & $\begin{array}{l}\text { Fraction } \\
\text { slow }(1-M)\end{array}$ \\
\hline Acer platanoides & 22.69 & 1.06 & 0.12 & 0.88 \\
Acer $x$ freemanii & 36.89 & 1.04 & 0.22 & 0.78 \\
Fraxinus pennsylvanica & - & 1.23 & 0 & 1 \\
Quercus bicolor & 20.79 & 0.57 & 0.05 & 0.95 \\
Tilia cordata & 20.44 & 0.96 & 0.22 & 0.78
\end{tabular}




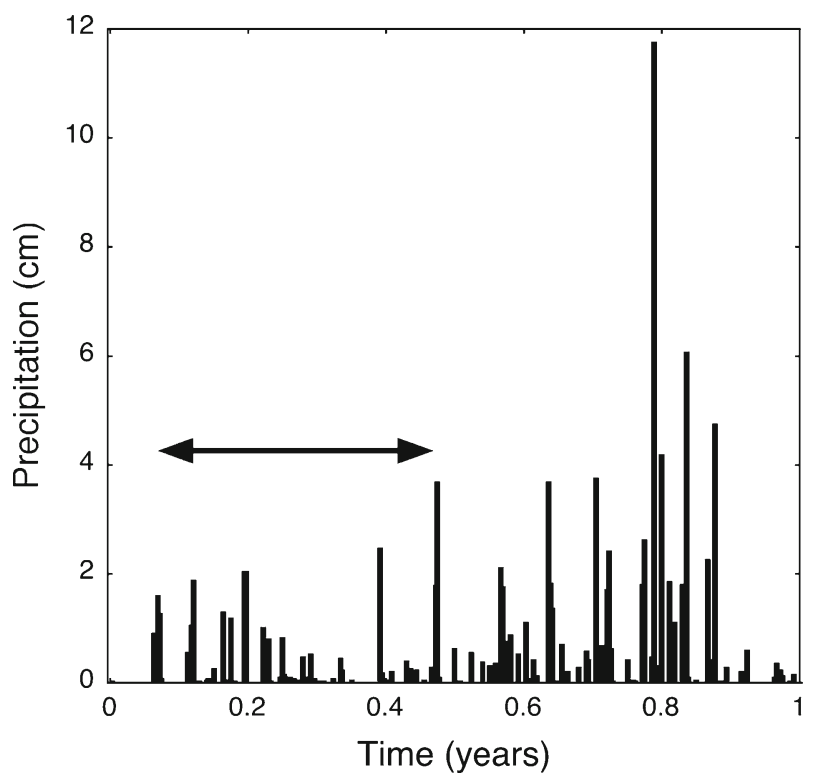

Fig. 1 Daily precipitation during the year of the experiment. The $\mathrm{x}$-axis refers to the time since initiation of the experiment. The arrow indicates the period during the year when precipitation fell as snow

the high initial N concentrations, and correspondingly large "fast" (and small "slow") fractions in Acer x freemanii and Tilia cordata.

Litter of all species, except Quercus, had lost on average $78 \%$ of its initial ash free dry mass after 1 year of decomposition (Fig. 2). Quercus litter lost $54 \%$ of its initial mass by this time. After 0.04 years, species did not differ significantly in the proportion mass remaining (one-way ANOVA, $P=0.13$ ). After 1 year, species differed significantly (one-way ANOVA, $P<0.0001$ ), with Quercus bicolor having more mass remaining (slower decomposition) than all other species (Tukey's HSD, $P=0.05$ ).

Litter of all species exhibited some $\mathrm{N}$ immobilization (net $\mathrm{N}$ incorporation into litter by colonizing decomposer microbes) over the course of the year, and litter of most of the species had retained more than half of its initial $\mathrm{N}$ mass after 1 year (Figs. 3 and 4). After losing about $50-60 \%$ of its initial mass, litter of all species stopped immobilizing $\mathrm{N}$ and lost $\mathrm{N}$ in proportion to mass loss (Fig. 4), although Quercus bicolor was still immobilizing $\mathrm{N}$ by the end of 1 year, due to its low rate of mass loss.

Litter P mass exhibited a more complex pattern than litter N. After the first period of $\mathrm{P}$ loss, most litter types exhibited two to three additional periods of $\mathrm{P}$ immobilization followed

Table 2 Initial litter chemistry for five species studied. All parameters are expressed in percent of total mass. Values are means (standard errors). $n=3$

\begin{tabular}{lllllll}
\hline Species & $\mathrm{N}$ & $\mathrm{P}$ & Cell solubles & Hemicellulose & Cellulose & Lignin \\
\hline Acer platanoides & $1.22(0.01)$ & $0.096(0.004)$ & $26.6(1.8)$ & $39.4(1.5)$ & $17.8(0.3)$ & $16.5(0.2)$ \\
Acer x freemanii & $1.57(0.02)$ & $0.134(0.010)$ & $64.3(0.4)$ & $14.0(0.6)$ & $11.2(0.1)$ & $10.9(0.1)$ \\
Fraxinus pennsylvanica & $0.96(0.13)$ & $0.162(0.002)$ & $50.0(1.4)$ & $15.5(1.3)$ & $23.1(0.1)$ & $11.8(0.2)$ \\
Quercus bicolor & $1.16(0.13)$ & $0.099(0.002)$ & $42.6(0.2)$ & $11.1(0.2)$ & $22.4(0.2)$ & $24.3(0.1)$ \\
Tilia cordata & $1.39(0.03)$ & $0.162(0.010)$ & $38.9(1.7)$ & $28.4(1.4)$ & $18.7(0.2)$ & $14.4(0.6)$ \\
\hline
\end{tabular}




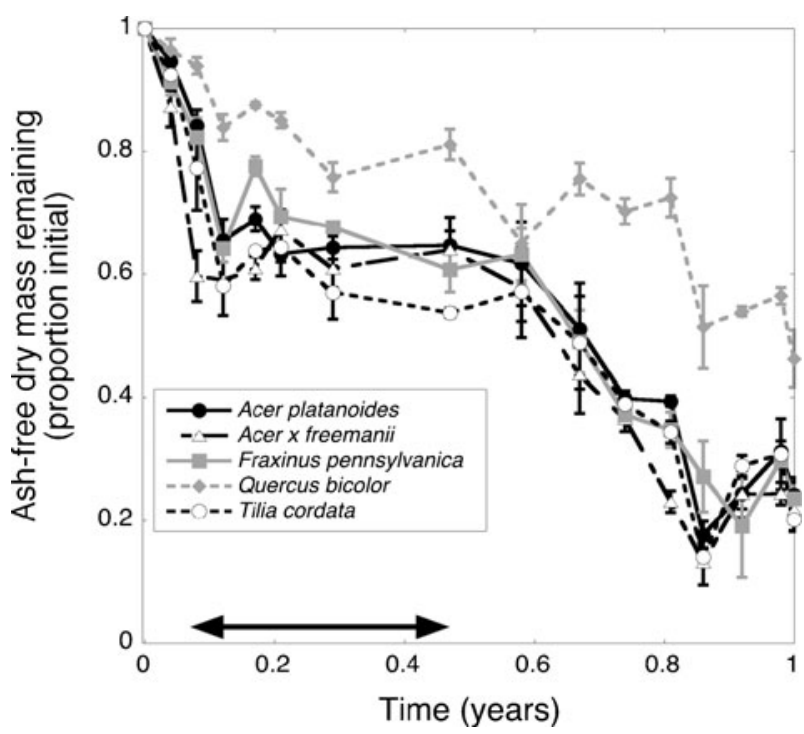

Fig. 2 Proportion ash-free dry mass remaining for litter of five tree species decomposing in a gutter. The arrow indicates the time during the year when precipitation fell as snow

by P loss, and by the end of 1 year Quercus bicolor and Acer platanoides were immobilizing $\mathrm{P}$, while the remaining species had lost about $50 \%$ of their initial P (Figs. 5 and 6).

Species differed significantly in the amount of $\mathrm{N}$ that leached from litter in a short-term leaching experiment, with the two Acer species and Tilia cordata exhibiting higher leaching

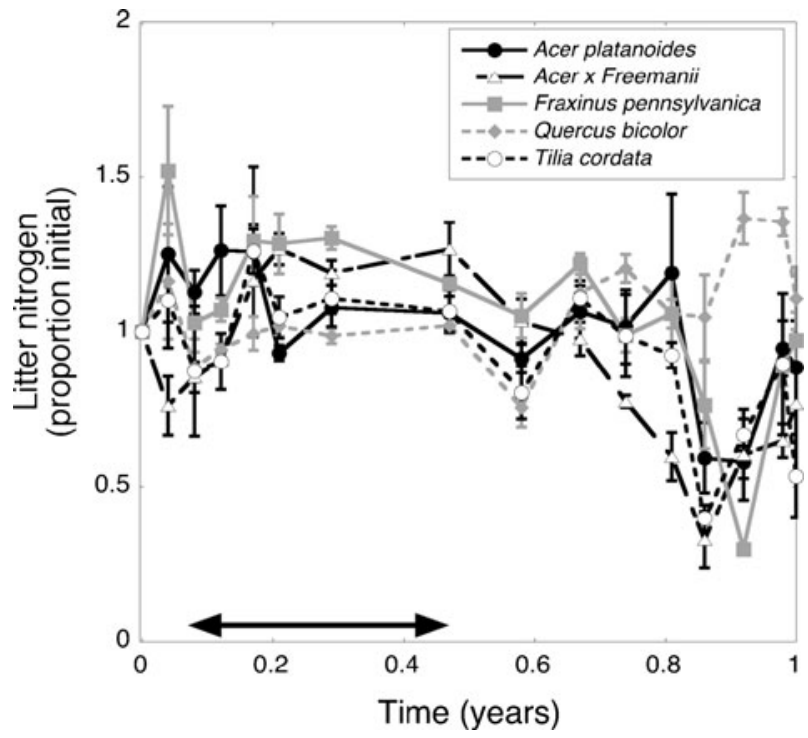

Fig. 3 Proportion initial $\mathrm{N}$ mass for litter of five tree species decomposing in a gutter. The arrow indicates the time during the year when precipitation fell as snow 


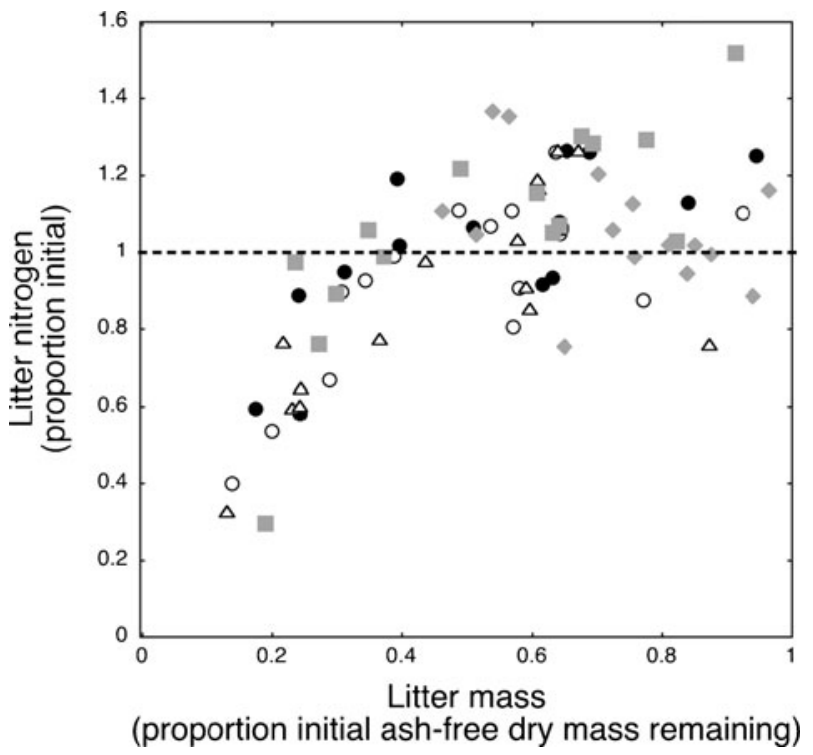

Fig. 4 Proportion initial $\mathrm{N}$ mass versus proportion initial ash-free dry mass remaining for all species at all time points (each point represents the mean for each species at each harvest for each species). See Fig. 2 for explanation of symbols. Above the dashed line litter is immobilizing $\mathrm{N}$; below it, litter is releasing $\mathrm{N}$

losses of TDN than the other two species (Fig. 7). Leaching losses increased by approximately 3 -fold between 0.5 and $24 \mathrm{~h}$, and the majority of $\mathrm{N}$ leached was as DON (Table 3). For N, species differed significantly after both 0.5 and $24 \mathrm{~h}$ (one-way ANOVA, $P<0.0001$ ). Tilia cordata and Acer platanoides leached significantly more $\mathrm{N}$ than did all other species,

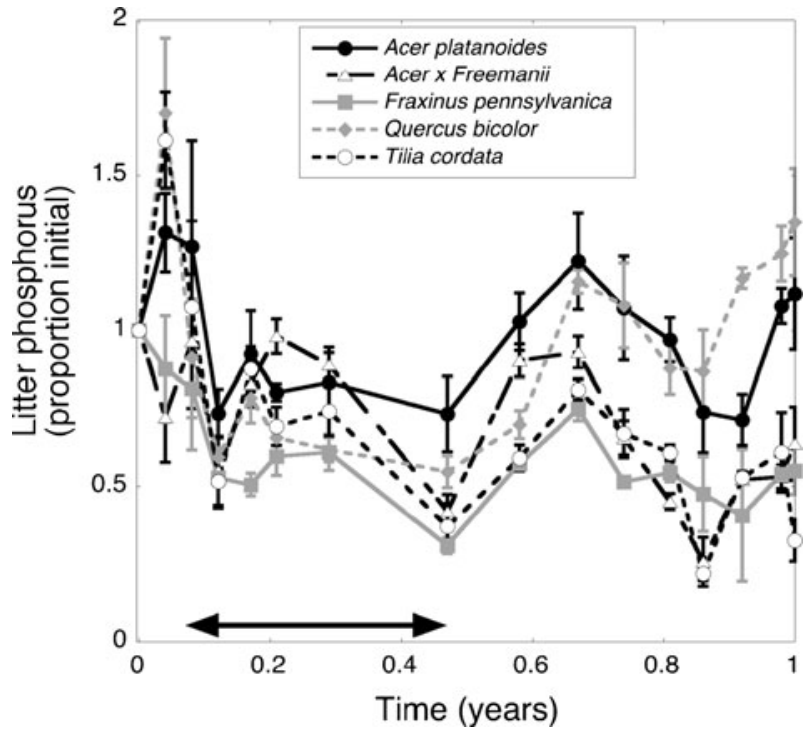

Fig. 5 Proportion initial $\mathrm{P}$ mass for litter of five tree species decomposing in a street gutter. The arrow indicates the time during the year when precipitation fell as snow 


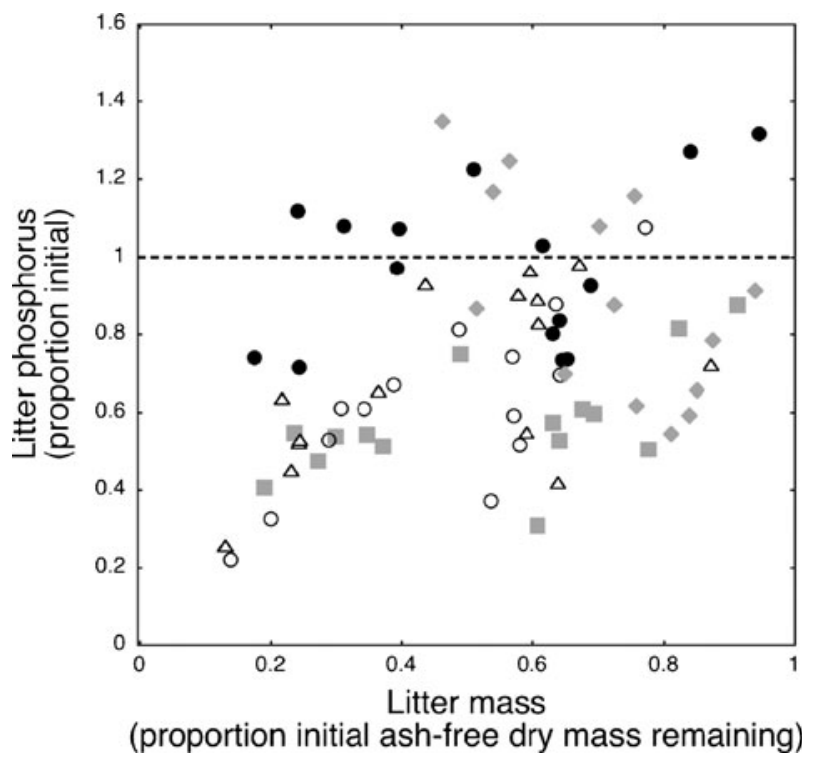

Fig. 6 Proportion initial $\mathrm{P}$ mass versus proportion initial ash-free dry mass remaining for all species at all time points (each point represents the mean for each species at each harvest for each species). See Fig. 2 for explanation of symbols. Above the dashed line litter is immobilizing P; below it, litter is releasing P

followed by Acer $x$ freemannii (Tukey's HSD, $P=0.05$ ). Quercus bicolor and Fraxinus pennsylvanica leached the least $\mathrm{N}$ and were not different from one another, except after $24 \mathrm{~h}$.

Species also differed significantly after both 0.5 and $24 \mathrm{~h}$ in the amount of $\mathrm{P}$ that leached from litter (Fig. 7, one-way ANOVA, $P<0.0001$ ). After $0.5 \mathrm{~h}$, species ranked similarly as for $\mathrm{N}$, but differences among species were not as consistently significant. Tilia cordata, Acer platanoides, and Acer x freemanii were not significantly different from one another but leached significantly more $\mathrm{P}$ than did Quercus bicolor and Fraxinus pennsylvanica, which were not different from one another. After $24 \mathrm{~h}$, the rankings among species had changed and species were more distinct. Tilia cordata and Quercus bicolor leached significantly more $\mathrm{P}$ than all other species. The two Acer spp. leached significantly less $\mathrm{P}$ than the other three species. Phosphorus leaching losses were comparable in magnitude to $\mathrm{N}$ leaching losses, and also differed significantly among species, again with Tilia cordata and the two Acer species leaching the most TDP (Fig. 7). After $0.5 \mathrm{~h}$, about one-third of the leached $\mathrm{P}$ was present as SRP and two-thirds as DOP (Table 3). After $24 \mathrm{~h}$, most of the leached DOP had been mineralized to SRP, as values of DOP were near zero (note that negative values of DOP resulted because DOP was calculated by subtracting SRP from TDP and analytical error sometimes caused SRP values to exceed those of TDP; these values were set to zero).

When expressed as proportions of the initial pools of $\mathrm{N}$ and $\mathrm{P}$ in the leaf litter that were leached, $\mathrm{N}$ and $\mathrm{P}$ leaching differed markedly from one another, with $\mathrm{P}$ exhibiting potential for substantial leaching losses (Fig. 8). After $0.5 \mathrm{~h}$, less than $4 \%$ of the initial $\mathrm{N}$ was leached, whereas $9-26 \%$ of the initial $\mathrm{P}$ was leached. After $24 \mathrm{~h}$, less than $10 \%$ of initial $\mathrm{N}$ was leached, whereas $28-88 \%$ of the initial $\mathrm{P}$ was leached. Species differed significantly in the proportions of initial $\mathrm{N}$ and $\mathrm{P}$ pools leached, with patterns among species largely resembling those for absolute amounts of $\mathrm{N}$ and $\mathrm{P}$ that leached (Fig. 7 versus Fig. 8). For N, species differed significantly after both 0.5 and 24 h (one-way ANOVA, $P<0.0001$ ). After 0.5 and $24 \mathrm{~h}$, Tilia cordata and Acer platanoides leached a significantly greater fraction of their 
initial $\mathrm{N}$ pools than did all other species, followed by Acer $x$ freemanii (Tukey's HSD, $P=$ 0.05). Quercus bicolor and Fraxinus pennsylvanica leached the least $\mathrm{N}$ and were not different from one another, except after $24 \mathrm{~h}$. For P, species differed significantly after both 0.5 and $24 \mathrm{~h}$ (one-way ANOVA, $P<0.0001$ ). After $0.5 \mathrm{~h}$, Acer platanoides leached the greatest fraction and Fraxinus pennsylvanica the lowest, with the other species intermediate and not different from one another. After $24 \mathrm{~h}$, the rankings among species had changed and

Fig. 7 The total mass of dissolved nitrogen (top) and phosphorus (bottom) leached from litter over 0.5 and $24 \mathrm{~h}$
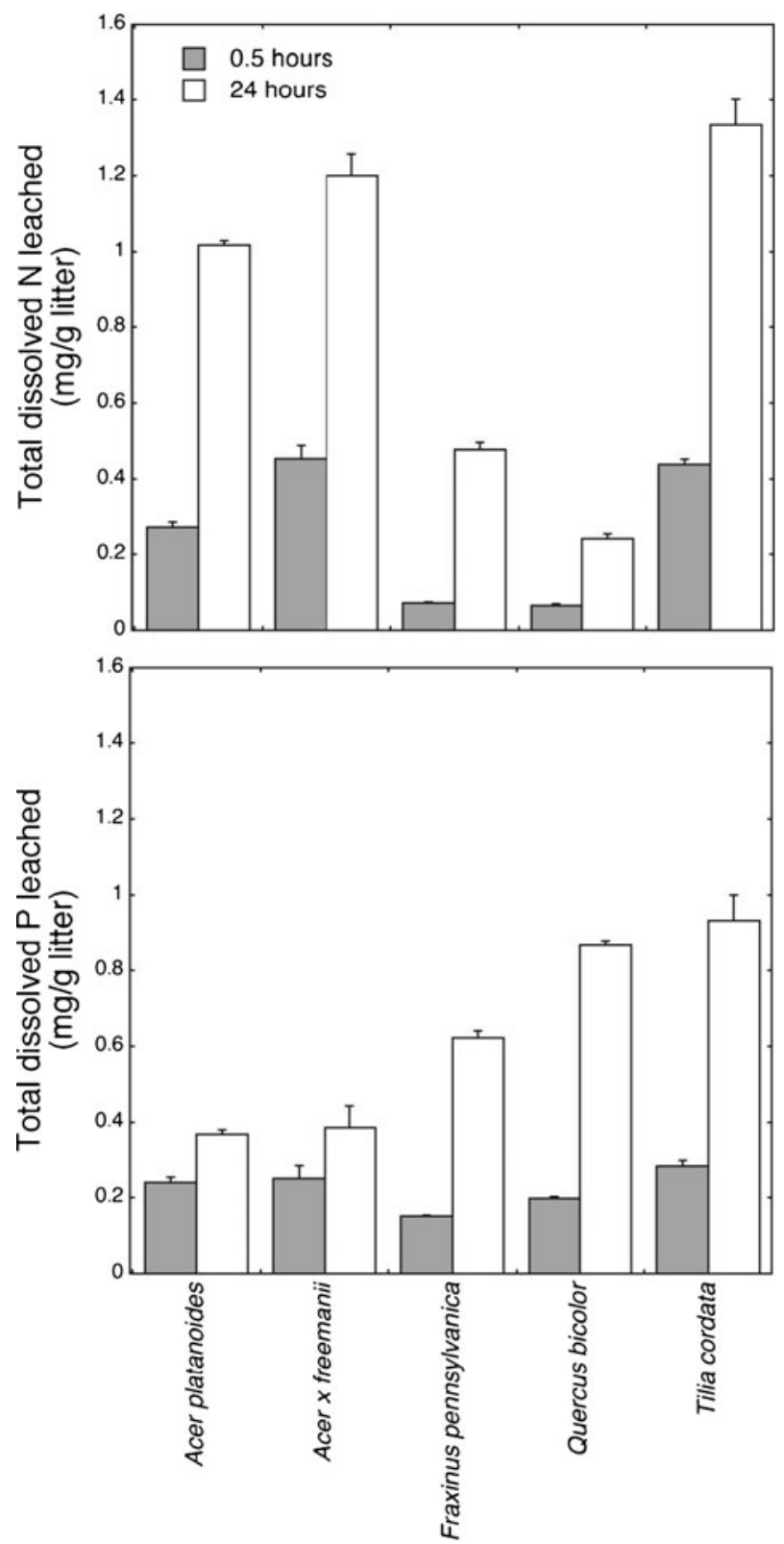

Species 


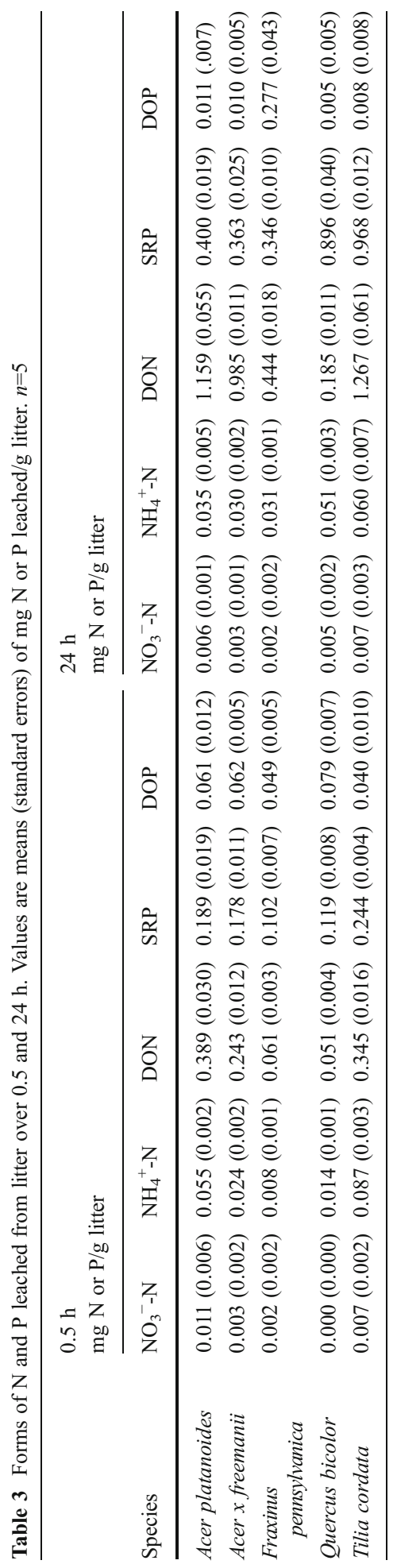


Fig. 8 The proportions of the initial masses of nitrogen (top) and phosphorus (bottom) leached from litter over 0.5 and $24 \mathrm{~h}$
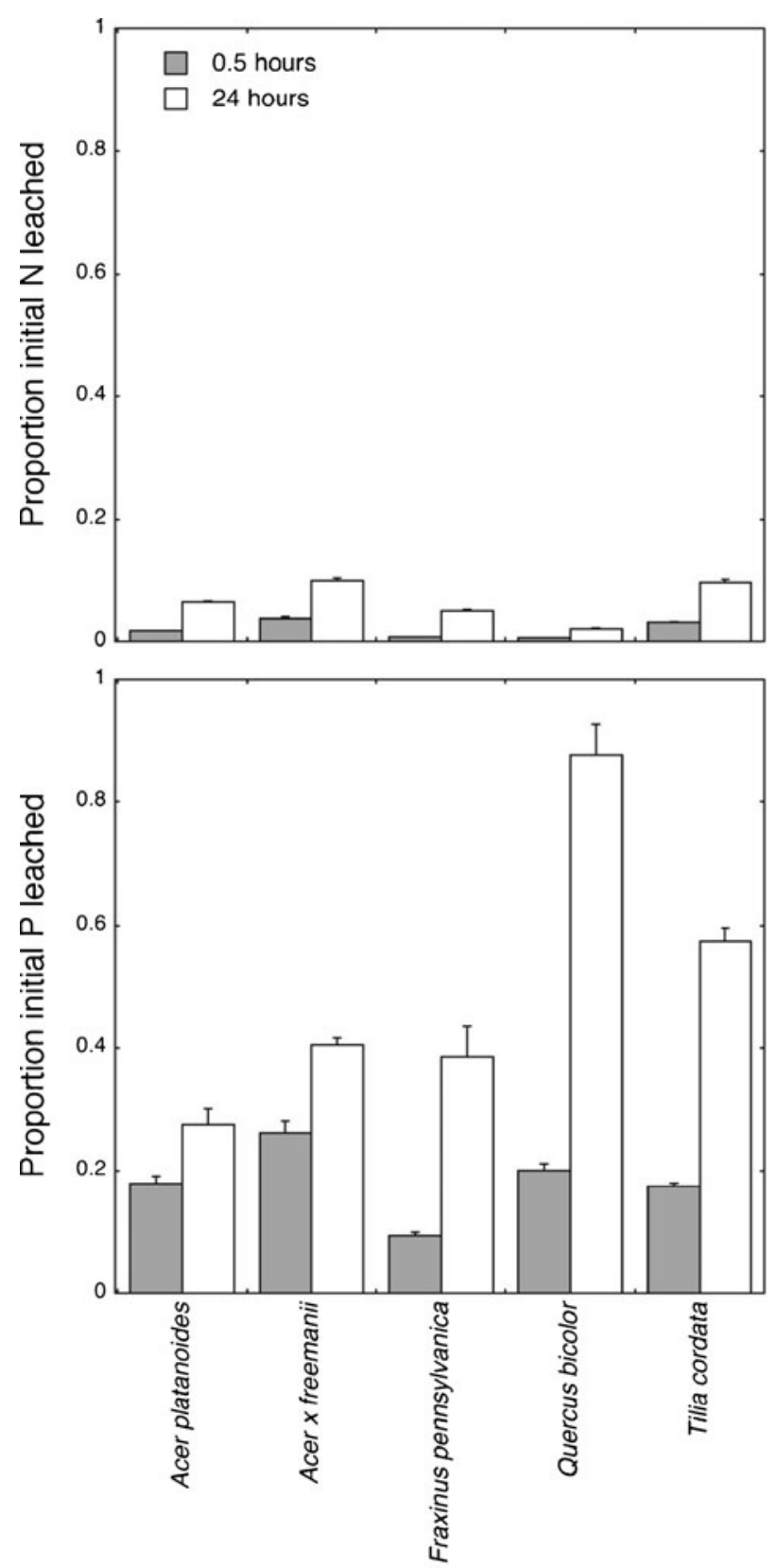

Species

species were more distinct. Quercus bicolor leached the largest fraction of its initial P pool, followed by Tilia cordata. Acer $x$ freemanii leached the lowest fraction of its initial P.

Only a small fraction $(<2 \%)$ of the initial litter $\mathrm{C}$ was leached as DOC after $0.5 \mathrm{~h}$ (Table 4). However, after $24 \mathrm{~h}$, up to $15 \%$ of the initial $\mathrm{C}$ was leached, with Fraxinus pennsylvanica and Tilia cordata exhibiting the largest proportional leaching losses of C. 
Table 4 DOC leached from litter over 0.5 and $24 \mathrm{~h}$. Values are means (standard errors) of $\mathrm{mg} \mathrm{C}$ leached/g litter or proportion initial C leached. $n=5$

\begin{tabular}{|c|c|c|c|c|}
\hline \multirow[b]{2}{*}{ Species } & \multicolumn{2}{|c|}{$\begin{array}{l}\text { DOC leached } \\
\text { (mg C/g litter) }\end{array}$} & \multicolumn{2}{|c|}{$\begin{array}{l}\text { DOC leached } \\
\text { (proportion initial C) }\end{array}$} \\
\hline & $0.5 \mathrm{~h}$ & $24 \mathrm{~h}$ & $0.5 \mathrm{~h}$ & $24 \mathrm{~h}$ \\
\hline \multirow[t]{2}{*}{ Acer platanoides } & 10.47 & 31.25 & 0.02 & 0.07 \\
\hline & $(0.63)$ & $(0.90)$ & $(0.00)$ & $(0.00)$ \\
\hline \multirow[t]{2}{*}{ Acer $x$ freemanii } & 9.15 & 69.64 & 0.02 & 0.15 \\
\hline & $(0.42)$ & $(0.61)$ & $(0.00)$ & $(0.00)$ \\
\hline \multirow[t]{2}{*}{ Fraxinus pennsylvanica } & 3.62 & 32.23 & 0.01 & 0.07 \\
\hline & $(0.10)$ & $(1.75)$ & $(0.00)$ & $(0.00)$ \\
\hline \multirow[t]{2}{*}{ Quercus bicolor } & 0.94 & 5.75 & 0.00 & 0.01 \\
\hline & $(0.09)$ & $(0.41)$ & $(0.00)$ & $(0.00)$ \\
\hline \multirow[t]{2}{*}{ Tilia cordata } & 11.81 & 47.97 & 0.03 & 0.11 \\
\hline & $(0.40)$ & $(0.87)$ & $(0.00)$ & $(0.00)$ \\
\hline
\end{tabular}

\section{Discussion}

Litter decomposition

In contrast to our expectations, decomposition proceeded rapidly in the gutter, supporting the notion that substantial processing of allochthonous organic matter occurs on impervious surfaces before it moves into storm drains, the "headwaters" of urban hydrologic networks (Kaushal and Belt 2012). Thus, impervious surfaces themselves might be considered the first-order "streams" in an urban watershed continuum, with characteristics (slope, drainage pattern, adjacent vegetation) that likely influence organic matter processing and nutrient dynamics. What these salient characteristics are, and how they affect organic matter dynamics, deserve further study.

Compared to decomposition rates of leaf litter of congeners in natural forests and prairies at the Cedar Creek Long Term Ecological Research site (35 km north of the study site) (Hobbie 2008; Hernández and Hobbie 2008; McBrayer and Cromack 1980), decomposition rates were about twice as fast in the gutter. Rapid decomposition in the gutter may have resulted from several factors. First, litter $\mathrm{N}$ concentrations were higher for urban species than their congeners in nearby natural areas. For example, litter of the two Acer species studied here had three times the $\mathrm{N}$ concentrations of Acer saccharum litter collected at Cedar Creek Ecosystem Science Reserve. Litter P concentrations were similar between urban and natural area congeners. Second, temperatures are higher in the urban area (especially on road surfaces) than in the surrounding region because of urban heat island effects, perhaps stimulating decomposition (Pouyat and Carreiro 2003). Third, in contrast to our initial expectation that lack of nutrient sources and decomposer microbes might limit decomposition rates in the gutter, we observed a number of potential nutrient and microbial sources to the street gutter that could have fueled rapid decomposition. Grass clippings and wind-borne sediments were present in the gutter at various times during the experiment, nutrients could have entered the gutter through runoff from the adjacent fertilized turfgrass, and $\mathrm{N}$ could have been transported atmospherically from nearby fertilized experimental agricultural fields and automobile traffic. Fourth, driving over the bags at regular intervals (as happens in most streets) likely contributed to fragmentation that could have accelerated decomposition by increasing surface area of litter exposed to microbial attack. Indeed, litter collected from in 
this experiment was more fragmented than that collected in experiments we have conducted in nearby forests and grasslands (personal observation). Regardless of the cause, decomposition rates were high, such that only about $20-40 \%$ of the initial mass was remaining after 1 year, compared to 50-85\% in natural forests and savanna in the region (Hobbie 2008; Hernández and Hobbie 2008; McBrayer and Cromack 1980).

Decomposition exhibited unique dynamics in the street, as well, exhibiting a period of very rapid initial mass loss (of up to $22 \%$ ) for the first 1.5 months of decomposition. This was followed by very little decomposition over the winter snow-covered period, followed by relatively rapid decomposition after snow melt, such that a double-exponential model was the best description of mass loss dynamics. These dynamics contrast those described by a single exponential decay model (a constant rate of mass loss), the model most commonly used to describe terrestrial decomposition data for studies lasting 1 year or less (Adair et al. 2010).

Overall, decomposition rates were comparable to those measured in other urban terrestrial studies, and initial rates approached (or matched) those measured in urban streams. For example, rates of decomposition in this study were in the range of those measured in urban forest stands in warmer regions (e.g., the eastern United States) (Pouyat et al. 1997; Pouyat and Carreiro 2003; Pavao-Zuckerman and Coleman 2005). The rapid initial rates of decomposition seen here were more rapid than initial decomposition rates of litter of congeners measured in an urban stream in the eastern United States (Swan et al. 2008) and were similar to rates measured in Australian urban streams for litter with high carbon quality (Imberger et al. 2008).

Thus, there likely are attributes of the street that are more stream-like and promote rapid initial mass loss, for example, overland water flow during rain events that may facilitate leaching. This interpretation is further suggested by the fact that substantial fractions of all litter types were soluble materials (27-64\%) and that the two species with the largest fast fractions $(M)$, Acer $x$ freemanii and Tilia cordata, also had the greatest proportional loss of $\mathrm{C}$ as DOC in the leaching experiments (Table 4). Warm, nutrient-rich conditions in the street likely promote high microbial activity both during and between rain events, during times when litter is moist.

Nevertheless, the rates we measured here may be lower than decomposition rates in many streets in the area for the following reasons. Because we required a large secure area for this study, we chose to conduct the study in a single relatively protected parking lot. The parking lot curbs lack tree canopy cover and the lot receives very little traffic. By contrast, residential streets where most urban leaf litter decomposes likely experience more frequent automobile traffic (parking and driving) resulting in litter being driven over more than the once per week imposed in our study. Increased fragmentation associated with traffic likely would accelerate decomposition. In addition, residential streets likely develop more substantial leaf litter mats in the fall from tree cover that could increase moisture retention and supply nutrients to decomposers, further accelerating decomposition. Finally, the parking lot was constructed to slope away from the curbs to a central drain, minimizing runoff down the gutter itself that would contribute to leaching of litter. Thus, although the rates of decomposition were relatively rapid in our study, rates in nearby residential streets likely would be even higher.

The soluble material lost rapidly during initial decomposition may have important downstream effects on urban aquatic ecosystems, as DOC represents an important organic $\mathrm{C}$ source to stream and lake food webs. Although particulate matter derived from leaf inputs to streets may be removed by sweeping or trapped in retention basins, DOC losses from leaf litter leaching would be rapidly transported into storm drains, and, as for streams (Meyer et al. 1998; McArthur and Richardson 2002; Slack and Feltz 1968), provide a pulsed input of 
labile organic matter for microbial metabolism. Leaf litter leaching of DOC also could help explain relatively higher concentrations of DOC observed in urban watersheds compared to nearby forested ones (Newcomer et al. 2012; Petrone 2010) and in stormwater runoff, particularly during fall (unpublished data).

Both the initial lignin and the initial $\mathrm{N}$ concentration were strong predictors of litter decomposition, as has been seen in other studies (Melillo et al. 1982; Cornwell et al. 2008), including at nearby Cedar Creek (Hobbie 2008). This similarity in chemical drivers of decomposition suggests that decomposition in the street gutter is likewise mediated by microbial activity, as opposed to solely physical processes (such as fragmentation into smaller particles that escaped the litter bags).

\section{Litter nutrient dynamics}

The dynamics of $\mathrm{N}$ were similar to those seen in non-urban temperate settings, with a period of $\mathrm{N}$ immobilization (an increase in $\mathrm{N}$ mass due to decomposer $\mathrm{N}$ uptake into litter) followed by N release (Staaf and Berg 1981; Manzoni et al. 2010; Parton et al. 2007). These dynamics are consistent with the small fraction of $\mathrm{N}$ that was lost in the leaching experiment $(<4 \%$ after $0.5 \mathrm{~h},<10 \%$ after $24 \mathrm{~h}$ ) and suggests that $\mathrm{N}$ is highly retained in litter, even though mass loss is rapid in the initial stages of decomposition, likely because of the high C:N ratio of fresh litter compared to the $\mathrm{C}: \mathrm{N}$ ratio of microbial biomass (Cleveland and Liptzin 2007) and the relative insolubility of $\mathrm{N}$ in fresh litter, that hinders leaching. Indeed, $\mathrm{N}$ was not consistently released from litter until $60 \%$ of mass was lost. Nitrogen dynamics may have been influenced by $\mathrm{N}$ fertilization of turfgrass adjacent to the curb gutter, which happened $0.01,0.56$, and 0.75 years into the experiment. At each of these time points, litter of most species exhibited a period of net immobilization, perhaps because of increased $\mathrm{N}$ supply associated with fertilizer that got into the gutter or with increased $\mathrm{N}$ in runoff.

Phosphorus dynamics were somewhat different from those of $\mathrm{N}$, with periods of immobilization and release throughout the year. Notably, some species exhibited losses of up to $50 \%$ of initial $\mathrm{P}$ mass, even in the initial stages of decomposition, such that $\mathrm{P}$ dynamics were largely uncoupled from litter mass dynamics. These different dynamics of $\mathrm{N}$ and $\mathrm{P}$ may arise because $\mathrm{N}$ is held in plant litter and associated decomposer biomass mostly as organic $\mathrm{N}$, whereas $\mathrm{P}$ may be present in both litter and microbes as either organic $\mathrm{P}$ or as inorganic $\mathrm{P}$ that can be readily leached. For example, on average $<1 \%$ of leaf $\mathrm{N}$ is inorganic, compared to one-third of the P in leaves (Ostertag 2010). Thus, even though microbial demand for P is likely high during the initial stages of decomposition, $\mathrm{P}$ can be leached under the right conditions of precipitation. Unlike $\mathrm{N}$, inputs of $\mathrm{P}$ from fertilizer likely did not contribute to litter $\mathrm{P}$ dynamics, as there was no $\mathrm{P}$ fertilizer applied to nearby turfgrass during the experiment. However, turfgrass soils in the region have relatively high available $\mathrm{P}$ (Barten 2005) and could have contributed $\mathrm{P}$ to litter bags via runoff, wind-borne deposition or erosion.

The nutrient dynamics of litter decomposing in the street were similar to those observed in the laboratory leaching study in that species exhibited a much higher capacity to leach $\mathrm{P}$ than to leach N. Short-term (30 min.) leaching results were similar to those of another study of many of the same species in Madison, WI (Dorney 1986). Long-term (24 h) leaching results resembled those of another study (Uselman et al. 2012) that found a high soluble $\mathrm{P}$ fraction in leaf litter ( $72 \%$ ), compared to only about $11 \%$ of leaf litter $\mathrm{N}$, among species of pine, ceanothus, incense-cedar, fir, and oak. In that study, in which microbial activity was chemically suppressed during leaching, most of the soluble $\mathrm{P}$ was leached as inorganic P, whereas most of the soluble $\mathrm{N}$ was leached as DON. These results are similar to our 0.5 -hour 
results, which presumably reflect the soluble constituents in leaf litter before substantial microbial processing occurred. A study in Australia similarly found that a high proportion of litter P leached in laboratory studies (Qiu et al. 2002) and in the field during the rainy season (McComb et al. 2007).

Nevertheless, our results indicated significant differences between nutrient dynamics in the street and in the laboratory leaching study. Litter of some species that exhibited substantial leaching losses of $\mathrm{N}$ and especially $\mathrm{P}$ in the laboratory did not exhibit such losses in the street, likely because of dry conditions during the first 3.5 weeks of deployment (Fig. 1). In fact, some species that lost substantial $\mathrm{P}$ in the laboratory study exhibited a period of increase in $\mathrm{P}$ mass in the street. Notably, some litter types still retained a high proportion of their initial P 1 year after the litter bags were deployed in the street even though they exhibited substantial P losses initially or after an early period of immobilization (e.g. Quercus bicolor, Acer platanoides). These results suggest that there is a high capacity for leaf litter decomposing in the street to immobilize $\mathrm{P}$ from the environment, likely as microbes take up $\mathrm{P}$ to meet nutritional demands for breaking down and using the organic matter as an energy source.

Leaf litter $\mathrm{P}$ mass, and to a lesser degree $\mathrm{N}$ mass, were dynamic-increasing and decreasing throughout the study period - although the causes and timing of these dynamics are unclear. The dynamics did not relate to precipitation patterns, as changes in $\mathrm{N}$ or $\mathrm{P}$ (either in total mass or concentration) between any two harvests were not correlated with either the cumulative, daily mean, or daily maximum precipitation during that period, regardless of whether the time during which precipitation fell as snow was included in the analysis (analyses not shown). Thus, leaching losses triggered by rain events appear to have been offset by $\mathrm{P}$ immobilization into litter by decomposers between rain events. Immobilization may have been stimulated during times when external inputs of nutrients to the street gutter were high, e.g., during times of high deposition, turfgrass runoff, or grass clipping leaching or decomposition, which can be substantial (Waschbusch et al. 1999). However, that possibility cannot be assessed, as we did not measure those inputs.

Implications for stormwater nutrient management

Our results provide further evidence that street tree leaf litter can be an important source of nutrients and organic $\mathrm{C}$ to stormwater drainage networks, ultimately contributing to eutrophication of urban and downstream surface waters. Indeed, we have observed that exports of $\mathrm{N}$ and $\mathrm{P}$ in stormwater among six urban watersheds varies in direct proportion to tree canopy cover (unpublished data) and a past study showed correlations between tree cover and $\mathrm{P}$ concentrations in runoff (Waschbusch et al. 1999). Thus, street sweeping may be an effective method of reducing sources of nutrients to stormwater (Dorney 1986; Cowen and Lee 1973; Waschbusch et al. 1999; Selbig and Bannerman 2007). In an ongoing experiment of street sweeping under various tree canopy levels and sweeping frequencies, we are finding that street sweeping can remove large quantities of nutrients, especially during fall, and that sweeping can be cost effective for removing nutrients from stormwater relative to structural stormwater control methods (Kalinosky et al. unpublished).

The leaching experiments presented in this paper show that timely removal of street debris following leaf litterfall may be necessary to reduce nutrient fluxes from streets to storm drains, particularly for $\mathrm{P}$, which has the potential to be readily leached during precipitation events. Furthermore, any litter washing down storm drains into catch basins or infiltration trenches will become submerged in water, similar to our leaching experiments. Our results show that litter can release substantial amounts of dissolved $\mathrm{P}$ in these conditions, 
which would then pass through stormwater infrastructure that is designed to settle out or trap particulate $\mathrm{P}$ (Wallace et al. 2008). Additional research is needed to determine decomposition rates for leaf litter trapped in stormwater catch basins and ponds.

Our results further indicate that street tree species may differ substantially in their potential contributions to nutrients that are released during the decomposition process. Thus, urban forest managers should consider the potential of leaf litter to contribute to eutrophication as an additional selection criterion for street tree species.

Acknowledgments We thank Karin Sather and John Brockgreitens for useful discussion and help in the laboratory and Claire Baglien, Ayeza Jamil, Cathleen Nguyen, Grace Park, Madhvi Patel, and Jennifer Pederson for assistance. This research was supported by an Environmental Protection Agency Section 319(h) Program grant and a University of Minnesota Discovery Grant.

\section{References}

Adair EC, Hobbie SE, Hobbie RK (2010) Single-pool exponential decomposition models: potential pitfalls in their use in ecological studies. Ecology 91(4):1225-1236

Barten JM (2005) Stormwater management for shoreline and "near" shoreline homeowners. LakeLine 25:21-24

Carreiro MM, Howe K, Parkhurst DF, Pouyat RV (1999) Variation in quality and decomposability of red oak leaf litter along an urban-rural gradient. Biol Fertil Soils 30:258-268

Cleveland CC, Liptzin D (2007) C: N: P stoichiometry in soil: is there a "Redfield ratio" for the microbial biomass? Biogeochemistry 85(3):235-252

Cornwell WK, Cornelissen JHC, Amatangelo K, Dorrepaal E, Eviner VT, Godoy O, Hobbie SE, Hoorens B, Kurokawa H, Peréz-Harguindeguy N, Quested HM, Santiago LS, Wardle DA, Wright IJ, Aerts R, Allison SD, van Bodegom P, Brovkin V, Chatain A, Callaghan TV, Díaz S, Garnier E, Gurvich DE, Kazakou E, Klein JA, Read J, Reich PB, Soudzilovskaia NA, Vaieretti MV, Westoby M (2008) Plant species traits are the predominant control on litter decomposition rates within biomes worldwide. Ecol Lett 11:1065-1071

Cotrufo MF, De Santo AV, Alfani A, Bartoli G, De Cristofaro A (1995) Effects of urban heavy metal pollution on organic matter decompositio in Quercus ilex L. woods. Environ Pollut 89:81-87

Cowen WF, Lee GF (1973) Leaves as a source of phosphorus. Environ Sci Technol 7:853-854

De Mott WR, Gulati RD, Siewertsen K (1998) Effects of phosphorus-deficient diets on the carbon and phosphorus balance of Daphnia magna. Limnol Oceanogr 43:1147-1161

Dorney JR (1986) Leachable and total phosphorus in urban street tree leaves. Water Air Soil Pollut 28:439443

Fritze H (1988) Influence of urban air pollution on needle litter decomposition and nutrient release. Scand J For Res 3:291-297

Hernández DL, Hobbie SE (2008) Effects of fire frequency on oak litter decomposition and nitrogen dynamics. Oecologia 158:535-543

Hobbie SE (2008) Nitrogen effects on litter decomposition: a five-year experiment in eight temperate grassland and forest sites. Ecology 89:2633-2644

Imberger SJ, Walsh CJ, Grace MR (2008) More microbial activity, not abrasive flow or shredder abundance, accelerates breakdown of labile leaf litter in urban streams

Kaushal SS, Belt KT (2012) The urban watershed continuum: evolving spatial and temporal dimensions. Urban Ecosyst 15(2):409-435

Manzoni S, Trofymow JA, Jackson RB, Porporato A (2010) Stoichiometric controls on carbon, nitrogen, and phosphorus dynamics in decomposing litter. Ecol Monogr 80:89-106

McArthur MD, Richardson JS (2002) Microbial utilization of dissolved organic carbon leached from riparian litterfall. Can J Fish Aquat Sci 59:1668-1676

McBrayer JF, Cromack K Jr (1980) Effect of snow-pack on oak-litter breakdown and nutrient release in a Minnesota forest. Pedobiol 20:47-54

McComb AJ, Qiu S, Bell RW, Davis JA (2007) Catchment litter: a phosphorus source mobilized during seasonal rainfall. Nutr Cycl Agroecosyst 77:179-186

McDonnell MJ, Pickett STA, Groffman P, Bohlen P, Pouyat RV, Zipperer WC, Parmelee RW, Carreiro MM, Medley K (1997) Ecosystem processes along an urban-to-rural gradient. Urban Ecosyst 1:21-36 
Melillo JM, Aber JD, Muratore JF (1982) Nitrogen and lignin control of hardwood leaf litter decomposition dynamics. Ecology 63:621-626

Meyer JL, Wallace JB, Eggert SL (1998) Leaf litter as a source of dissolved organic carbon in streams. Ecosystems 1:240-249

Newcomer TA, Kaushal SS, Mayer PM, Shields AR, Canuel EA, Groffman PM, Gold AJ (2012) Influence of natural and novel organic carbon sources on denitrification in forest, degraded urban, and restored streams. Ecol Monogr 82(4):449-466

Nowak DJ, Greenfield EJ (2012) Tree and impervious cover change in U.S. cities. Urban For Urban Green 11:21-30

Ostertag R (2010) Foliar nitrogen and phosphorus accumulation responses after fertilization: An example from nutrient-limited Hawaiian forests. Plant and Soil 334 (85-98)

Parton WA, Silver WL, Burke IC, Grassens L, Harmon ME, Currie WS, King JY, Adair EC, Brandt LA, Hart SC, Fasth B (2007) Global-scale similarities in nitrogen release patterns during long-term decomposition. Science 315:361-364

Pavao-Zuckerman MA, Coleman DC (2005) Decomposition of chestnut oak (Quercus prinus) leaves and nitrogen mineralization in an urban environment. Biol Fertil Soils 41:343-349

Petrone KC (2010) Catchment export of carbon, nitrogen, and phosphorus across an agro-urban land use gradient, Swan-Canning River system, southwestern Australia. JGR 115. doi:10.1029/2009JG001051

Pouyat RV, Carreiro MM (2003) Controls on mass loss and nitrogen dynamics of oak leaf litter along an urban-rural land-use gradient. Oecologia 135:288-298

Pouyat RV, McDonnell MJ, Pickett STA (1997) Litter decomposition and nitrogen mineralization in oak stands along an urban-rural land use gradient. Urban Ecosyst 1:117-131

Qiu S, McComb AJ, Bell RW (2002) Phosphorus-leaching from litterfall in wetland catchments of the Swan Coastal Plain, southwestern Australia. Hydrobiologia 472:95-105

Selbig WR, Bannerman RT (2007) Evaluation of street sweeping as a stormwater-quality-management tool in three residential basins in Madison, Wisconsin. U.S. Geological Survey

Slack KV, Feltz HR (1968) Tree leaf control on low flow water quality in a small Virgina stream. Environ SciTechnol 2(2):126-131

Staaf H, Berg B (1981) Accumulation and release of plant nutrients in decomposing Scots pine needle litter. Long-term decomposition in a Scots pine forest II. Can J Bot 60:1561-1568

Swan CM, Healey B, Richardson DC (2008) The role of native riparian tree species in decomposition of invasive tree of heaven (Ailanthus altissima) leaf litter in an urban stream. Ecoscience 15(1):27-35

Uselman SM, Qualls RG, Lilienfein J (2012) Quality of soluble organic C, N, and P produced by different types and species of litter: Root litter versus leaf litter. Soil Biol Biochem 54:57-67

Wallace TA, Ganf GG, Brookes JD (2008) A comparison of phosphorus and DOC leachates from different types of leaf litter in an urban environment. Freshw Biol 53:1902-1913

Waschbusch RJ, Selbig WR, Bannerman RT (1999) Sources of phosphorus in stormwater and street dirt from two urban residential basins in Madison, Wisconsin, 1994-1995. Water Resources Investigations Report 99-4021. U.S. Geological Survey, Middleton, WI

Wieder RK, Lang GE (1982) A critique of the analytical methods used in examining decomposition data obtained from litter bags. Ecology 63:1636-1642 